\title{
Acute phase response elicited by experimental bovine diarrhea virus (BVDV) infection is associated with decreased vitamin $D$ and $E$ status of vitamin-replete preruminant calves ${ }^{1}$
}

\author{
B. J. Nonnecke, ${ }^{2}$ J. L. McGill, J. F. Ridpath, R. E. Sacco, J. D. Lippolis, and T. A. Reinhardt \\ Ruminant Diseases and Immunology Research Unit, National Animal Disease Center, USDA, Agricultural Research Service, Ames, IA 50010
}

\section{ABSTRACT}

Studies in young animals have shown an association between vitamin deficiencies and increased risk of infectious disease; however, there is a paucity of information regarding the effect of acute infection on the vitamin status of the vitamin-replete neonate. To characterize the effects of acute infection on vitamin D and $\mathrm{E}$ status of the neonate, 6 vitamin-replete preruminant Holstein bull calves were experimentally infected with bovine viral diarrhea virus (BVDV; strain BVDV2-1373). Six mock-inoculated calves served as controls. Sustained pyrexia, leukopenia, and asynchronous increases in serum haptoglobin and serum amyloid A characterized the response of calves to infection with BVDV. Infection was also associated with increased serum IFN- $\gamma$, IL-2, and IL-6 concentrations. During the last $8 \mathrm{~d}$ of the 14-d postinoculation period, serum 25-hydroxyvitamin $\mathrm{D}$ and $\alpha$-tocopherol concentrations in infected calves decreased by 51 and $82 \%$, respectively. The observed inverse association between vitamin $\mathrm{D}$ and $\mathrm{E}$ status and serum amyloid A in infected calves suggests that the infection-induced acute phase response contributed to the reduced vitamin status of these animals. Additional studies are necessary to determine if the negative effect of infection on status are unique to this specific infection model or is representative of preruminant calf's response to acute infection. Studies are also needed to characterize mechanisms underlying infection-related changes in vitamin $\mathrm{D}$ and $\mathrm{E}$ status and to determine whether additional vitamin $\mathrm{D}$ or $\mathrm{E}$ supplementation during an acute infection diminishes disease severity and duration in the young animal.

Key words: bovine viral diarrhea virus (BVDV), preruminant calf, neonatal vitamin D status, vitamin E status and infection, acute phase response

\section{Received April 27, 2014.}

Accepted May 23, 2014.

${ }^{1}$ Names are necessary to report factually on available data; however, the USDA neither guarantees nor warrants the standard of the product, and the use of the name by the USDA implies no approval of the product to the exclusion of the other that may also be suitable.

${ }^{2}$ Corresponding author: nonnecke@iowatelecom.net

\section{INTRODUCTION}

Numerous studies in young animals have shown an association between vitamin deficiencies and increased risk of infectious diseases (McNally et al., 2009; Battersby et al., 2012); however, there is a paucity of information regarding the effect of acute infection on the status of the vitamin-replete, young animal.

The endocrine physiology of vitamin $\mathrm{D}$ in cattle is well described, especially as it relates to its critical role in promoting calcium uptake from intestines, bones, and kidneys (Horst et al., 1994; NRC, 2001). Studies investigating the immunomodulatory role of vitamin $\mathrm{D}$ in the bovine immune system indicate that it also modulates, ex vivo, functional capacities of cells involved with innate and adaptive immunity via intracrine vitamin D signaling mechanisms (Ametaj et al., 1996; Nelson et al., 2010b, 2011, 2012). Although only a few studies have examined the in vivo effects of vitamin D on the bovine immune system, Lippolis et al. (2011) were the first to identify the potential benefits of vitamin D in the treatment of a clinical bacterial mastitis in dairy cattle, suggesting a nonantibiotic, adjunct role for vitamin $\mathrm{D}$ in the management of infectious disease. The authors propose that the positive effects of vitamin D treatment are likely due to its enhancement of the innate immune system in the vitamin D-deficient milk compartment of the mammary gland. Sacco et al. (2012) examined the effects of vitamin D status on lung pathology and cytokine response of the preruminant calf experimentally infected with bovine respiratory syncytial virus (BRSV). Although the extent of lung pathology was comparable in calves with low and high vitamin D status, this study was the first to show that BRSV infection activates the vitamin D intracrine signaling pathway in the inflamed lung of the preruminant calf. Streptococcus uberis mastitis also activates the intracrine vitamin D pathway in $\mathrm{CD}^{+} 4^{+}$cells from the infected mammary gland (Nelson et al., 2010a).

25 -Hydroxyvitamin D $[25(\mathrm{OH}) \mathrm{D}]$ in association with vitamin D-binding protein is the predominant circulating vitamin $\mathrm{D}$ metabolite and is considered the best indicator of vitamin D status in cattle and humans 
(Horst et al., 1994; Holick, 2009). Although there is debate regarding associations between vitamin $\mathrm{D}$ status or vitamin D supplementation and potential health benefits, evidence suggests that vitamin D adequacy in humans is achieved when serum $25(\mathrm{OH}) \mathrm{D}$ concentrations exceed $30 \mathrm{ng} / \mathrm{mL}$ (Holick, 2009). Multiple epidemiologic studies in young children indicate an association between vitamin $\mathrm{D}$ deficiency and an increased risk of respiratory infection (McNally et al., 2009; Battersby et al., 2012). For the preruminant calf, serum 25(OH) D concentrations representing sufficiency, insufficiency, and deficiency have not been established and the current recommended vitamin $\mathrm{D}$ requirement $(600 \mathrm{IU} / \mathrm{kg}$ of DM, applicable to milk replacer and starter feed) has not changed since 1989 (NRC, 2001). Calves fed milk replacer, however, consistently achieve serum $25(\mathrm{OH})$ $\mathrm{D}$ concentrations greater than $30 \mathrm{ng} / \mathrm{mL}$ (Nonnecke et al., 2009a, 2010) due to the high vitamin D content in commercial milk replacers, often 10- to 20 -fold more than the current NRC recommendation (NRC, 2001). In contrast, milk-fed calves not provided supplemental vitamin D frequently have low circulating $25(\mathrm{OH})$ D concentrations (Rajaraman et al., 1997; Kreuger et al., 2014), often decreasing to levels that would be indicative of clinical deficiency in humans $(\leq 10 \mathrm{ng} / \mathrm{mL}$; Holick, 2009).

Evans and Bishop (1922) were the first to identify vitamin $\mathrm{E}$ and its obligatory role in reproduction. It was subsequently shown to be the predominant lipidsoluble antioxidant in mammalian tissues and serum (reviewed by Burton, 1994) preventing propagation of free radical reactions. In its natural form, vitamin $\mathrm{E}$ can exist as tocopherols ( $\alpha, \beta, \gamma, \delta$ isoforms) as well as the corresponding tocotrienol isoforms. Because animals and humans are unable to synthesize tocopherols, dietary sources are required to ensure vitamin E adequacy. Uptake, tissue distribution, and metabolism of vitamin $\mathrm{E}$ have been described in numerous reviews. Briefly, vitamin $\mathrm{E}$ and other lipids enter the lymphatic system after intestinal absorption. All forms of vitamin $\mathrm{E}$ are transported to the liver in chylomicrons or their remnants; however, $\alpha$-tocopherol $(\boldsymbol{\alpha}-\mathbf{T})$, specifically $R R R-\alpha-\mathrm{T}$, preferentially appears in serum lipoproteins (predominantly in the high-density lipoprotein fraction in preruminant dairy calves; Ametaj et al., 2000) due to its specific selection by hepatic $\alpha-T$ transfer protein $(\alpha-T T P)$. Because $\alpha-T$ is specifically retained in the body, it is considered the most biologically active form of vitamin E. The majority of the other $\alpha-T$ isoforms are secreted in the bile or feces, although, in humans, $\gamma$-tocopherol $(\boldsymbol{\gamma}-\mathbf{T})$ is transferred at a lower rate by $\alpha$-TTP, resulting in tissue concentrations at $\leq 10 \%$ of $\alpha-T$ levels (Wolf, 2006). For this reason, serum $R R R$ -
$\alpha-T$ concentration is considered the best indicator of vitamin E status.

Vitamin E influences the health of most animal species, including dairy cattle (reviewed by Beck, 2007, and Politis, 2012). The role of vitamin E as it relates to the health of adult and young dairy cattle has been studied extensively. It has been shown to reduce the incidence and severity of mastitis and reproductive disorders in transition dairy cows, and enhance phagocytic and killing capacities of bovine neutrophils (reviewed by Politis, 2012, and Weiss, 1998). Supplementation of calves with vitamin $\mathrm{E}$ enhances the functional capacities of blood neutrophils and lymphocytes (Cipriano et al., 1982; Eicher-Pruiett et al., 1992; Higuchi and Nagahata, 2000). Few studies have examined the effect of infection on vitamin E status; however, acute LPS- or Escherichia coli-induced mastitis increases $\alpha-T$ concentrations in milk but not in serum (Barrett et al., 1997). Currently, there is dearth of information regarding the effects of acute infection on the vitamin $\mathrm{E}$ status of vitamin-replete preruminant calves.

National Animal Health Monitoring Service (2012) data indicate that approximately $43.4 \%$ of preweaned calves were affected by diarrheal and respiratory diseases in 2010 and that the mortality rate of preweaned calves ranges from 3.7 to $5.7 \%$. Of the pathogens affecting the health of young cattle, bovine viral diarrhea virus (BVDV), a pestivirus, is a significant cause of morbidity and mortality and, because of its immunosuppressive effects, may contribute to the susceptibility of the bovine neonate to respiratory disease. The nature of the bovine maternal, fetal, and neonatal response to BVDV infection has been reviewed recently (Kelling and Topliff, 2013). High morbidity, low mortality, minimal mucosal lesions, and normal immune responses characterize the majority of postnatal acute BVDV infections. In contrast, the preruminant calf's response to high-virulence, noncytopathic (ncp) BVDV genotype 2 (BVDV2), a less common cause of bovine viral diarrhea, is manifested by more severe pathology and increased mortality (Kelling and Topliff, 2013). Development of an experimental infection model (LieblerTenorio et al., 2002; Ridpath et al., 2013) utilizing the high virulence strain BVDV2-1373, isolated originally from a widespread outbreak of severe acute BVDV infection in Ontario (Carman et al., 1998; Ridpath et al., 2006), has provided a detailed analysis of the host response to high virulence BVDV2. This response is characterized by leukopenia, thrombocytopenia, wide dissemination of virus in host tissues, and severe lymphocyte depletion in lymphoid tissues (Stoffregen et al., 2000; Liebler-Tenorio et al., 2002; Ridpath et al., 2013). This infection model provides an approach for evaluat- 
ing the effects of an acute viral infection on the vitamin status of the neonatal calf.

Utilizing the BVDV-1373 infection model, the objective of the present study was to investigate the effects of an acute viral infection on the vitamin $\mathrm{D}$ and $\mathrm{E}$ status of the vitamin-replete calf.

\section{MATERIALS AND METHODS}

\section{Calf Management}

Handling and treatment of calves was conducted in accordance with the Animal Welfare Act as amended (7 USC, 2131-2156). Twelve colostrum-deprived calves were acquired from a local dairy at birth. Each calf was given a one-time oral dose $(1 \mathrm{~mL})$ of vitamin $\mathrm{A}$ and $\mathrm{D}$ $(500,000 \mathrm{IU} / \mathrm{mL}$ vitamin $\mathrm{A}$ and $75,000 \mathrm{IU} / \mathrm{mL}$ vitamin $\mathrm{D}_{3}$, Agripharm, Westlake, TX) and $2 \mathrm{~mL}$ of BoSe (2.19 $\mathrm{mg} / \mathrm{mL}$ sodium selenite and $50 \mathrm{mg} / \mathrm{mL}$ D- $\alpha$-tocopheryl acetate, Schering-Plough Animal Health, Union, NJ) i.m. within the first $4 \mathrm{~h}$ following birth.

Buffy-coat samples obtained from the calves before the beginning of the study were tested for BVDV using virus isolation as described previously (Bauermann et al., 2012). At this time, calves were tested for BVDVspecific serum antibody and for BVDV antigen in ear notch samples using a commercial antigen-capture ELISA (Herdcheck BVD-PI, Idexx Laboratories Inc., Westbrook, ME) in accordance with the manufacturer's directions (Bauermann et al., 2012). Results from these tests indicated that calves were not infected with BVDV at the beginning of the study (Ridpath et al., 2013).

Calves were maintained in biosafety level 2 containment during the entire study period. They were housed individually in elevated calf crates $(1.6 \mathrm{~m}$ long $\times 0.9 \mathrm{~m}$ wide $\times 0.9 \mathrm{~m}$ high) in a temperature-controlled barn during the first 2 wk after birth. During the first 48 $\mathrm{h}$ after birth, calves were fed infant formula (Similac, 2 cans in $1.5 \mathrm{~L}$ bottles of warm water at each feeding; Abbott Laboratories, Abbott Park, IL) twice daily

Table 1. Milk replacer composition ${ }^{1}$

\begin{tabular}{lc}
\hline Component & $\begin{array}{c}\mathrm{DM} \\
\text { analysis }\end{array}$ \\
\hline CP, \% & $\geq 22$ \\
Crude fat, \% & $\geq 20$ \\
Crude fiber, \% & $\leq 0.15$ \\
Calcium, \% & $\geq 0.75$ \\
Phosphorous, \% & $\geq 0.70$ \\
Ash, \% & $\leq 13.0$ \\
Added minerals, \% & $\leq 0.05$ \\
Vitamin A (retinyl acetate), U/kg $/ \mathrm{kg} / \mathrm{kg}$ & $\geq 66,139$ \\
Vitamin $\mathrm{D}_{3}$ (cholecalciferol), IU $/ \mathrm{kg}$ & $\geq 11,023$ \\
Vitamin E (tocopherol acetate), IU $/ \mathrm{kg}$ & $\geq 220.46$ \\
\hline
\end{tabular}

${ }^{1}$ Distributed by Purina Mills LLC (St. Louis, MO). and then transitioned to a $22 \% \mathrm{CP}$ and $20 \%$ fat milk replacer diet (Table 1) fed according to the manufacturer's recommendations. Calves were weighed weekly and the amount of milk replacer fed was adjusted at these times to allow for changes in live weight. Clean water was available between feedings and starter grain was not fed during the study.

At 2 wk of age, calves were moved from the crates and housed in groups based on experimental treatment (i.e., controls, $\mathrm{n}=6$, infected, $\mathrm{n}=6$ ). Feeding and housing during this period were performed as described previously (Liebler-Tenorio et al., 2002).

\section{Virus Preparation and Inoculation Procedure}

At approximately 4 wk of age, 6 of the 12 calves were inoculated with the high-virulence ncp strain of BVDV designated BVDV2-1373. Virus propagation and determination of virus titer were performed as described previously (Bauermann et al., 2012; Ridpath et al., 2013). Calves in the virus-exposure group $(\mathrm{n}=6)$ were inoculated via the nasal route (i.e., fluid instilled directly into nasal passages) with $5 \mathrm{~mL}$ of bovine turbinate cell culture lysate containing a virus load of $10^{6}$ TCID (tissue culture infectious dose)/mL. Control calves $(\mathrm{n}=6)$ were mock-inoculated with $5 \mathrm{~mL}$ of cell culture lysate prepared from noninfected bovine turbinate cells; the day of inoculation was designated d 0. Serum samples for acute phase protein and cytokine analyses as well as serum samples for fat-soluble vitamin analyses were collected from -2 to +14 d relative to the day of inoculation. Rectal temperatures and blood leukocyte numbers were recorded for samples collected on $\mathrm{d}-2,+2$, $+4,+6,+8,+10,+12$, and +14 . Control and infected calves were housed in separate rooms, each with highefficiency particulate air filters. Biosecurity measures included no sharing of equipment and the requirement that personnel shower before moving between rooms housing calves from different experimental groups. Calves were observed twice daily for clinical signs of disease.

\section{Quantification of the Positive Acute Phase Proteins Haptoglobin and Serum Amyloid A}

Serum haptoglobin $(\mathbf{H p})$ concentrations were determined as described previously (Nonnecke et al., 2009a) using a bovine-specific Hp ELISA (Immunology Consultants Laboratory Inc., Newberg, OR) following the manufacturer's instructions.

Serum amyloid A (SAA) concentrations were determined using a multispecies SAA ELISA (Tridelta Development Ltd., Maynooth, Co. Kildare, Ireland) following the manufacturer's instructions. The SAA 
standards provided in the kit ranged from 9.4 to 600 $\mathrm{ng} / \mathrm{mL}$. Absorbance of standards and test samples was determined at $450 \mathrm{~nm}$ with $630 \mathrm{~nm}$ as a reference using an automated ELISA plate-reader (FlexStation 3, Molecular Devices, Sunnyvale, CA).

\section{Quantification of Serum Cytokines}

Multiplex analysis of serum IFN- $\gamma$, IL-1 $\beta$, IL-2, IL-4, IL-6, and tumor necrosis factor (TNF)- $\alpha$ concentrations was performed using Searchlight Custom Bovine Arrays (Cira Custom Bovine 6-Plex Array Kit, Aushon Biosystems, Billerica, MA) according to the manufacturer's instructions. Using Searchlight array software, cytokine concentrations $(\mathrm{pg} / \mathrm{mL})$ in serum samples were quantified by referencing to a standard curve for each cytokine.

\section{Quantification of Fat-Soluble Vitamins}

Serum 25(OH)D concentrations were quantified using a competitive-inhibition ELISA (DL·D Diagnostika GmbH, Hamburg, Germany) following the manufacturer's instructions. This assay detects $25(\mathrm{OH}) \mathrm{D}_{3}$ as well as the lesser metabolite $25(\mathrm{OH}) \mathrm{D}_{2}$. As reported by the manufacturer, cross reactivity with vitamin $\mathrm{D}_{3}$, vitamin $\mathrm{D}_{2}$, and $24,25(\mathrm{OH})_{2} \mathrm{D}_{3}$ is $<0.05 \%$, with a detection limit for $25(\mathrm{OH}) \mathrm{D}$ of $1.6 \mathrm{ng} / \mathrm{mL}$.

Serum $1,25(\mathrm{OH})_{2} \mathrm{D}_{3}$ concentrations in the same samples were quantified using RIA as described previously by Hollis et al. $(1993,1996)$. Serum $\alpha-T$ and $\gamma-T$ were quantified by reverse-phase HPLC (Ametaj et al., 2000) using a modification of the method of Kaplan et al. (1987).

\section{Statistical Analyses}

Data were analyzed as a completely randomized design using Statview (version 5.0, SAS Institute Inc., Cary, NC) software. Data from Hp, SAA, cytokine, $25(\mathrm{OH}) \mathrm{D}, 1,25(\mathrm{OH})_{2} \mathrm{D}_{3}$, and $\alpha / \gamma-\mathrm{T}$ assays, each acquired en bloc at the conclusion of the study, were used in the analyses. Calf served as the experimental unit in the analysis of all data. Rectal temperatures, blood leukocyte numbers, and circulating concentrations of acute phase proteins, cytokines, and vitamins were analyzed as a split-plot with repeated-measures ANOVA. The model included fixed effects of treatment and time and treatment by time interaction, with calf included in the model as the random effect. Fisher's protected least significant difference (LSD) test was applied when the model identified significant $(P \leq 0.05)$ effects or interactions.
Pearson product-moment correlations, split by treatment (control vs. infected), were computed between circulating concentrations of $25(\mathrm{OH}) \mathrm{D}, \mathrm{Hp}$, SAA, $1,25(\mathrm{OH})_{2} \mathrm{D}_{3}$, and $\alpha-\mathrm{T}$. Correlations were considered significant at $P<0.01$ with $\mathrm{r} \geq 0.40$.

\section{RESULTS AND DISCUSSION}

\section{Clinical Response}

Pyrexia and lymphopenia/thrombocytopenia are consistent clinical responses of calves experimentally infected with high-virulence BVDV2 (Stoffregen et al., 2000; Liebler-Tenorio et al., 2002). Infected calves frequently have rectal temperatures exceeding $40^{\circ} \mathrm{C}$ for 3 or more days. Mean body temperatures of control and infected calves in the present study are shown in Figure 1a. Temperatures of infected calves were higher $(P \leq$ $0.05)$ on $d 4$ through 14 of the postinoculation period (PIP) than those recorded at the time of inoculation or on $\mathrm{d} 2$ postinoculation. The pyrexic response of infected calves was maximal on $\mathrm{d} 6,8$, and 10 of the PIP. Although temperatures of infected calves decreased $(P$ $\leq 0.05$ ) progressively from d 10 through 14 of the PIP, they exceeded $(P \leq 0.05)$ the temperatures of control calves at these times.

Total numbers of circulating leukocytes in control and infected calves during the study are shown in Figure 1b. From d 6 through 14 of the PIP, infected calves had markedly lower $(P \leq 0.05)$ blood leukocyte numbers than control calves. Leukocyte numbers in control calves did not change $(P>0.05)$ during the experimental period.

\section{Serum Hp and SAA Concentrations}

The acute phase reaction is a systemic physiological response to infection as well as tissue injury and is characterized by marked changes in a group of nonstructurally related proteins in blood and other biological fluids (reviewed by Ceciliani et al., 2012). In ruminants, marked quantitative changes in 2 of these acute phase proteins, $\mathrm{Hp}$ and SAA, occur in serum and other fluids in response to bacterial and viral infections and endotoxin-induced inflammation (Heegaard et al., 2000; Grönlund et al., 2003; Jacobsen et al., 2004; Müller-Doblies et al., 2004). Haptoglobin, originally identified as a key scavenger of hemoglobin, plays an antiinflammatory role by modifying functional capacities of monocytes and macrophages (i.e., promoting release of IL-10 and other antiinflammatory mediators) and neutrophils (i.e., downregulating lipoxygenase and cycloxygenase activity), and a bacteriostatic role by 

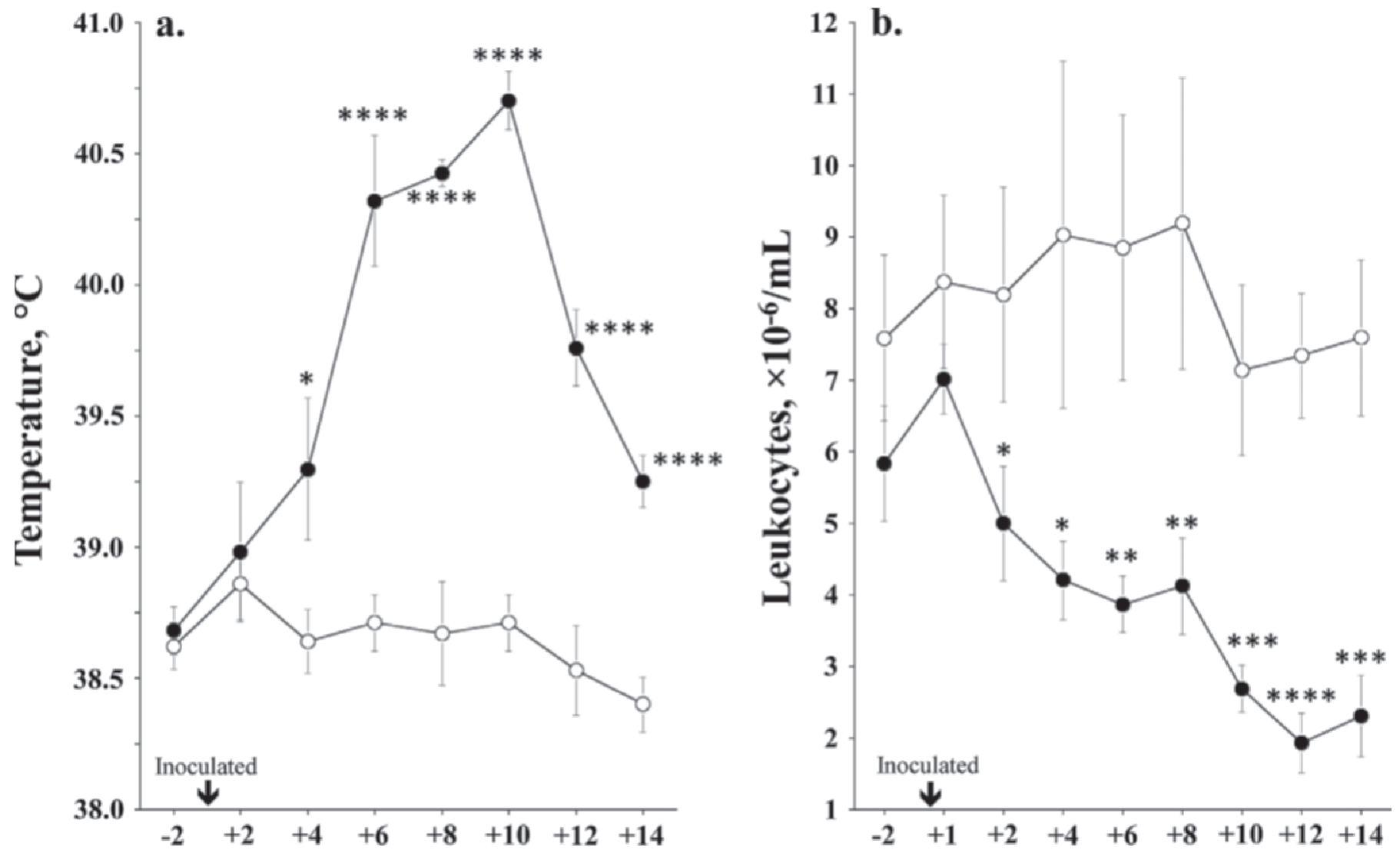

\section{Days relative to virus inoculation}

Figure 1. Mean $( \pm \mathrm{SEM})$ rectal temperatures (panel a) and peripheral blood leukocyte numbers (panel b) for calves mock-inoculated with virus-free cell culture lysate $(\mathrm{n}=6, \mathrm{O})$ or culture lysate containing bovine viral diarrhea virus (BVDV; $\mathrm{n}=6$, $\bullet$ ). Calves were inoculated on d 0 (indicated by arrow on abscissa). Treatment means that differed on a specific day are indicated by ${ }^{*} P<0.10$ (strong trend), $* * P<0.05$, $* * * P<0.01$, and $* * * * P<0.001$.

limiting the availability of hemoglobin-associated iron necessary for bacterial growth (Ceciliani et al., 2012).

Serum Hp and SAA in control and infected calves are shown in Figure 2. Preinoculation Hp concentrations in control and infected calves were not different $(P>0.05$; Figure 2a). During the PIP, Hp concentrations in infected calves were higher $(P<0.01)$ than those in control calves on d $6,8,10,12$, and 14 . When considering responses of infected calves only, Hp concentrations on d 6 through 14 of the PIP were higher $(P<0.01)$ than preinoculation concentrations, with the peak mean concentration occurring on $\mathrm{d} 8(149.6 \mu \mathrm{g} / \mathrm{mL})$ of the PIP. As a comparison, $\mathrm{Hp}$ responses of calves experimentally infected with ncp BVDV strain 110/39 were similar in magnitude and duration (Müller-Doblies et al., 2004).

The role of SAA in the acute phase response of ruminants has been reviewed recently (Ceciliani et al., 2012). Briefly, acute phase SAA is produced in the liver as consequence of the release of proinflam- matory cytokines during the acute phase response. A mammary-associated SAA has also been isolated and characterized and is expressed at higher levels during experimentally induced Staphylococcus aureus mastitis (Grönlund et al., 2003). Although biological functions of SAA are poorly understood, SAA has been shown in one or more animal species to bind cholesterol; act as a chemoattractant mediating migration, adhesion, and tissue infiltration of monocytes and neutrophils; and as an opsonin that promotes phagocytosis of bacteria by macrophages and neutrophils. In the present study, preinoculation SAA concentrations in control and infected calves were not different $(P>0.05$; Figure $2 \mathrm{~b})$. During the PIP, SAA concentrations in infected calves were higher $(P<0.01)$ than those in control calves on d 6 and 8 and again on d 12 and 14, suggesting that the SAA response of the neonate to BVDV2-1373 may be biphasic. In a related study (Müller-Doblies et al., 2004), SAA concentrations elicited by experimental 

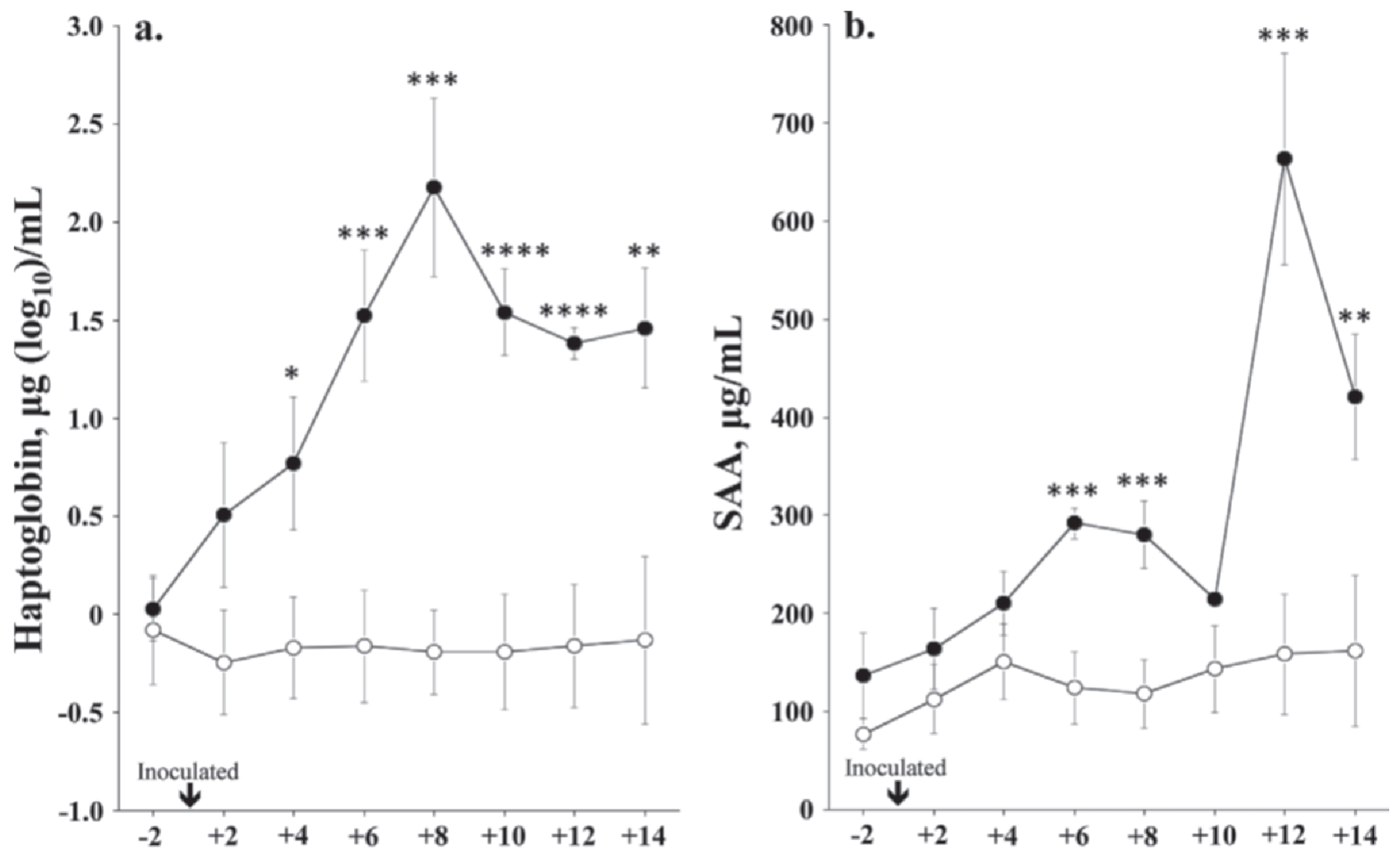

\section{Days relative to virus inoculation}

Figure 2. Mean ( \pm SEM) haptoglobin (panel a) and serum amyloid A (SAA, panel b) concentrations in sera from calves mock-inoculated with virus-free culture lysate $(\mathrm{n}=6, \mathrm{O})$ or with culture lysate containing bovine viral diarrhea virus $(\mathrm{BVDV} ; \mathrm{n}=6, \boldsymbol{\bullet})$. Calves were inoculated on d 0 (indicated by arrow on abscissa). Treatment means that differed on a specific day are indicated by $* P<0.10$ (strong trend), $* * P<0.05$, $* * * P<0.01$, and $* * * * P<0.001$. Haptoglobin data were transformed $\left(\log _{10}\right)$ before analysis.

BVDV infection peaked between 4 and $13 \mathrm{~d}$ of the PIP, with the maximum concentration (i.e., $200 \mu \mathrm{g} / \mathrm{mL}$ ) occurring on d 9 of the PIP. In contrast, the peak SAA response observed in the present study occurred on d 12 rather than $\mathrm{d} 9$ of the PIP, and the maximal response was substantially greater $(663.1 \mu \mathrm{g} / \mathrm{mL})$. The virulence of the strain of BVDV used in the present study likely contributed to the more pronounced SAA response by infected calves in the present study.

In the present study, $\mathrm{Hp}$ and SAA concentrations during the PIP were not correlated $(\mathrm{r}=0.16, P=$ 0.15 ), confirming previous observations (Jacobsen et al., 2004) that the synthesis of these 2 proteins during an acute phase response (Jacobsen et al., 2004; MüllerDoblies et al., 2004) differs mechanistically. As noted by Ceciliani et al. (2012), levels of the various acute phase proteins usually increase or decrease during the inflammatory response; however, changes are usually not uniform in all diseases or within an individual. The pronounced increase in both serum Hp and SAA in response to experimental BVDV infection suggests their potential use as biomarkers of the calf's response to acute BVDV infection.

\section{Serum Cytokine Concentrations}

Quantification of serum cytokine concentrations in control and infected calves showed no differences in IL$1 \beta$, IL-4, and TNF- $\alpha$ responses of control and infected calves at any time point $(P>0.05$; data not shown). As infection-induced changes in circulating concentrations of these specific cytokines can occur earlier than 4 d postinoculation (reviewed by Kelling and Topliff, 2013), changes may have been missed due to the sampling schedule followed in the current study. Results from a recent study (Molina et al., 2012) demonstrated earlier increases in serum TNF- $\alpha$, IFN- $\gamma$, and IL-12 and an associated decrease in IL-1 $\beta$ in older calves ( 8 to 9 
mo of age) inoculated with a low-virulence ncp BVDV1 strain. Effects of inoculation with BVDV2-1373, the strain used in the present study, on serum cytokine responses of neonatal calves at $<4 \mathrm{~d}$ postinoculation have not been reported.

Preinoculation serum IFN- $\gamma$, IL-2, and IL-6 concentrations in control and infected calves were not different $(P>0.05)$; however, their serum concentrations in control and infected calves differed $(P \leq 0.05)$ at one or more time points from d 4 to 14 of the PIP (Figure 3a, $\mathrm{b}$, and $\mathrm{c}$ ). Concentrations of IFN- $\gamma$ in infected calves exceeded those in control calves at all sampling times during this period, with the strongest responses occurring on $\mathrm{d} 8$ and 12 . Interleukin-2 and IL-6 responses of infected calves, in contrast, were of lower magnitude and occurred later in the course of infection. Interleukin-2 and IL-6 concentrations in infected calves exceeded ( $P$ $\leq 0.05)$ those of control calves on d 12 and 14 .

The asynchronous elevation in serum IFN- $\gamma$, IL-2, and IL- 6 concentrations in infected calves from d 4 to
14 of the PIP suggests that both T helper (Th) type 1 and proinflammatory responses occurred during the latter stages of the PIP. The Th1 response (Mosmann and Coffman, 1989), represented by the early and sustained elevation in serum IFN- $\gamma$ in infected calves, likely represents an antiviral response associated with the activation of $\mathrm{CD}^{+}$(Rhodes et al., 1999) and $\gamma \delta$ T-cell subsets. In the preruminant calf, $\gamma \delta \mathrm{T}$ cells represent a significant proportion of the T-cell population (Hein and Mackay, 1991). Recent evidence (McGill et al., 2013) indicates that $\gamma \delta \mathrm{T}$ cells from neonatal calves experimentally infected with bovine respiratory syncytial virus produce robust IFN- $\gamma$ responses to virus in vitro. In addition, our results indicating that ncp BVDV2 infection in calves elicited a pronounced IFN- $\gamma$ response differ from those of a recent study (Seong et al., 2013), suggesting that the response to BVDV2 infection is characterized typically by an attenuated or negligible IFN- $\gamma$ response. Taken together, these results suggest that ncp BVDV2 strains likely differ in their
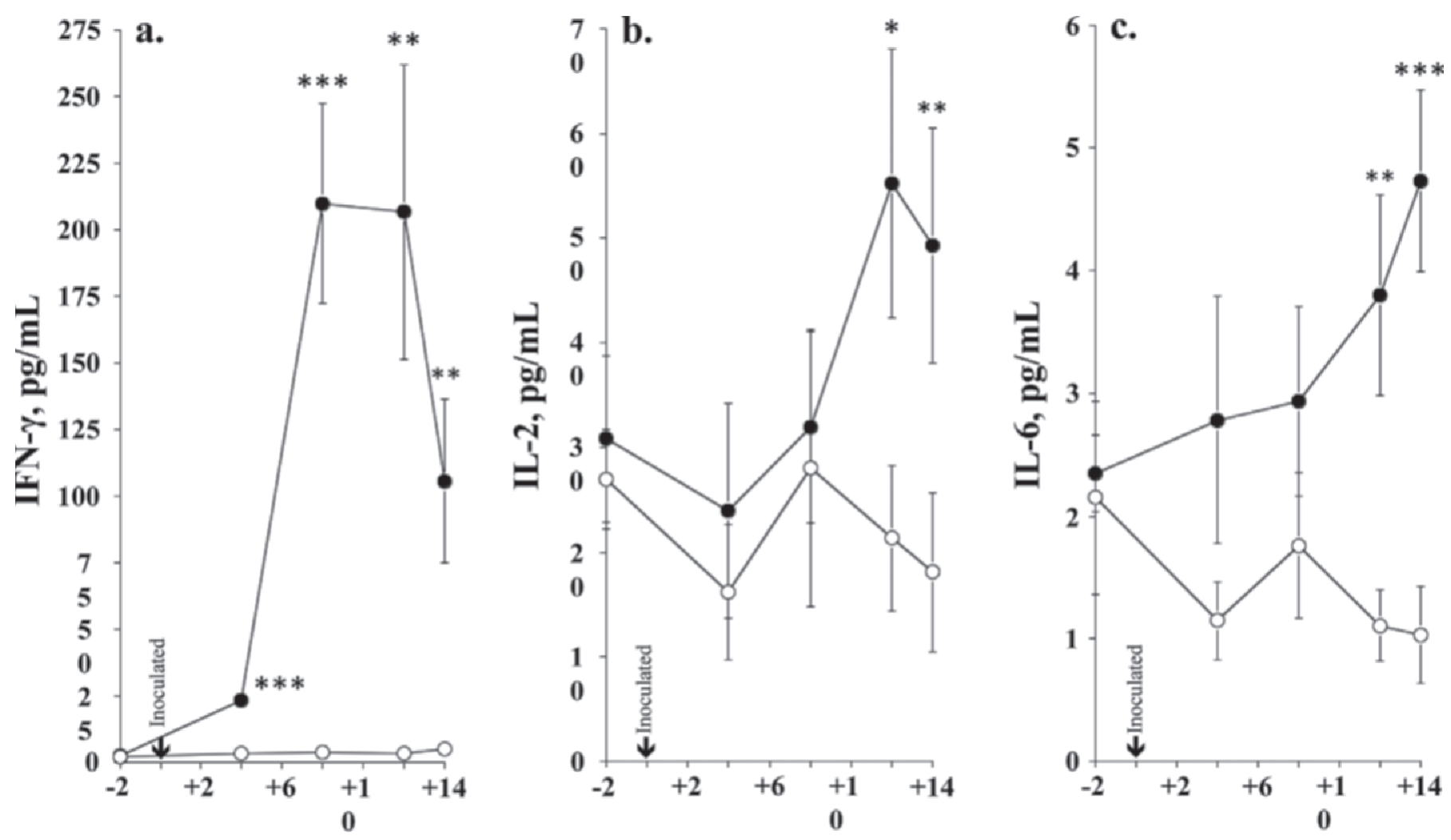

\section{Days relative to virus inoculation}

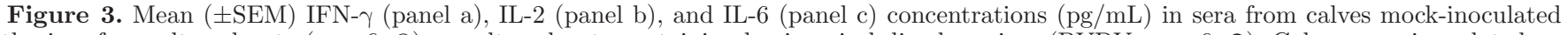
with virus-free culture lysate $(\mathrm{n}=6, \mathrm{O})$ or culture lysate containing bovine viral diarrhea virus $(\mathrm{BVDV} ; \mathrm{n}=6, \boldsymbol{\bullet})$. Calves were inoculated on d 0 (indicated by arrow on abscissa). Treatment means that differed on a specific day are indicated by ${ }^{*} P<0.10$ (strong trend), $* * P<0.05$, and ${ }^{* * *} P<0.01$. 
capacity to elicit IFN- $\gamma$ responses and that genotype (i.e., BVDV2 vs. BVDV1) may not be a consistent predictor of whether an IFN- $\gamma$ host-response will occur.

The increased serum IL-2 concentrations in infected calves on d 12 and 14 of the PIP (Figure 3b) may also reflect changes in T-cell activation and possible IL-2dependent development of regulatory $\mathrm{CD} 4^{+} \mathrm{T}$ cells (de la Rosa et al., 2004). In vitro studies suggest that when $\mathrm{CD} 8^{+} \mathrm{T}$ cells from seropositive cattle are cocultured with BVDV-infected monocytes, they produce Th1-like responses characterized by increased IL- 2 and IFN- $\gamma$ secretion (Rhodes et al., 1999).

Experimental evidence (Xing et al., 1998) suggests that induction of IL-6 during chronic intracellular infections contributes to the development of the acute phase response as well as limiting the severity of acute proinflammatory responses by promoting cellular immune responses against affected cells and of mucosal humoral responses against reinfection. The elevated IL-6 concentrations in infected calves on d 12 and 14 of the PIP (Figure 3c), a period of declining IFN- $\gamma$ concentrations (Figure 3a) and elevated acute phase protein concentrations (Figure 2), may represent the calf's attempt to limit the extent of tissue inflammatory responses. As suggested by Xing et al. (1998), elevated serum IL-6 concentrations may reflect an attempt by the host to return to a state of immune homeostasis.

\section{Infection-Induced Decrease in Vitamin D Status}

The vitamin D status of control and infected calves is shown in Figure 4a. Preinfection 25(OH)D concentrations in control $(43.9 \mathrm{ng} / \mathrm{mL})$ and infected $(47.4 \mathrm{ng} /$ $\mathrm{mL}$ ) calves were comparable and exceeded the minimum concentration considered indicative of vitamin $\mathrm{D}$ adequacy in humans $(\geq 30 \mathrm{ng} / \mathrm{mL}$; Holick, 2009). Although the status of noninfected calves remained unchanged during the study, $25(\mathrm{OH}) \mathrm{D}$ concentrations in infected calves decreased from $44.9 \mathrm{ng} / \mathrm{mL}$ (indicative of normal vitamin D status) to $22.0 \mathrm{ng} / \mathrm{mL}$ (indicative of vitamin $\mathrm{D}$ insufficiency) during the last $8 \mathrm{~d}$ of the PIP, a reduction of approximately $51 \%$. This rapid change suggests that the half-life of serum $25(\mathrm{OH}) \mathrm{D}$ in infected calves was approximately $8 \mathrm{~d}$, substantially shorter than the reported 15-d half-life of serum 25(OH) D in healthy humans (Jones, 2008). Additionally, the status of infected calves was lower than the status of control calves on d 12 and 14 of the PIP and, on d 8, 10,12 , and 14 of the PIP, was lower $(P \leq 0.01)$ than their preinoculation status.

These results are the first to demonstrate a pronounced, negative effect of an acute viral infection, characterized by leukopenia, pyrexia, and acute phase response, on the vitamin D status of the vitamin-replete preruminant calf. Few studies in cattle have shown a relationship between vitamin $\mathrm{D}$ status and pathogen exposure; however, Sorge et al. (2013) reported that circulating $25(\mathrm{OH}) \mathrm{D}_{3}$ concentrations in cows seropositive for Mycobacterium avium ssp. paratuberculosis were lower (59.1 vs. $64.5 \mathrm{ng} / \mathrm{mL}$ ) than those of seronegative cows. Furthermore, Autier et al. (2014) reviewed evidence that general inflammation may be an important contributor to disease associated with low vitamin D status. Our observations are important to the dairy calf producer because they indicate the potential for acute calf-hood infections to compromise severely vitamin D status, possibly justifying increased vitamin D supplementation during the early stages of clinical infection. These results also confirm the applicability of the preruminant calf as an animal model for evaluating vitamin or immune status of neonates (Nonnecke et al., 1999; Ametaj et al., 2000; Endsley et al., 2009; Nelson et al., 2012).

Mechanisms responsible for the rapid decrease in the vitamin D status of infected calves are not known; however, at least 2 possibilities may explain the rapid decline in serum 25(OH)D concentrations. Because BVDV-infected calves were anorexic during the latter part of the PIP, the availability of dietary vitamin $\mathrm{D}$, the primary source of vitamin D for milk replacer-fed calves housed indoors, would have been substantially reduced, resulting in a decrease in vitamin $\mathrm{D}$ status. Our results suggest that the half-life of $25(\mathrm{OH}) \mathrm{D}$ in virus-infected calves was approximately $8 \mathrm{~d}$, a much shorter period than the estimated 15-d half-life of $25(\mathrm{OH}) \mathrm{D}$ in healthy humans (Jones, 2008). Although the half-life of $25(\mathrm{OH}) \mathrm{D}$ in preruminant calves has not been reported, recent unpublished data from our laboratory yields an estimate of approximately $18 \mathrm{~d}$. This value was determined by monitoring serum $25(\mathrm{OH})$ $\mathrm{D}$ concentrations in healthy preruminant calves that received 50,000 IU of vitamin $\mathrm{D}$ at birth and were fed cow milk, a negligible source of $25(\mathrm{OH}) \mathrm{D}$ (Rajaraman et al., 1997), from 1 to $28 \mathrm{~d}$ of age.

The substantially shorter half-life of $25(\mathrm{OH}) \mathrm{D}$ in BVDV-infected calves versus healthy calves not receiving exogenous vitamin $\mathrm{D}$ suggests that the increased rate of disappearance of $25(\mathrm{OH}) \mathrm{D}$ in infected calves was infection related. Numerous studies have confirmed that leukocytes contributing to innate and adaptive immune responses express the vitamin D-activating enzyme 25-hydroxyvitamin $\mathrm{D}$-1 $\alpha$-hydroxylase (CYP27B1), that catalyzes the conversion $25(\mathrm{OH}) \mathrm{D}$ to $1,25(\mathrm{OH})_{2} \mathrm{D}_{3}$. This intracrine/paracrine production of $1,25(\mathrm{OH})_{2} \mathrm{D}_{3}$ triggered by pathogen recognition via toll-like receptors or antigen presentation has been shown to increase antibacterial capacity of monocytes and macrophages, modulate dendritic cell maturation, and, in lymphocyte 


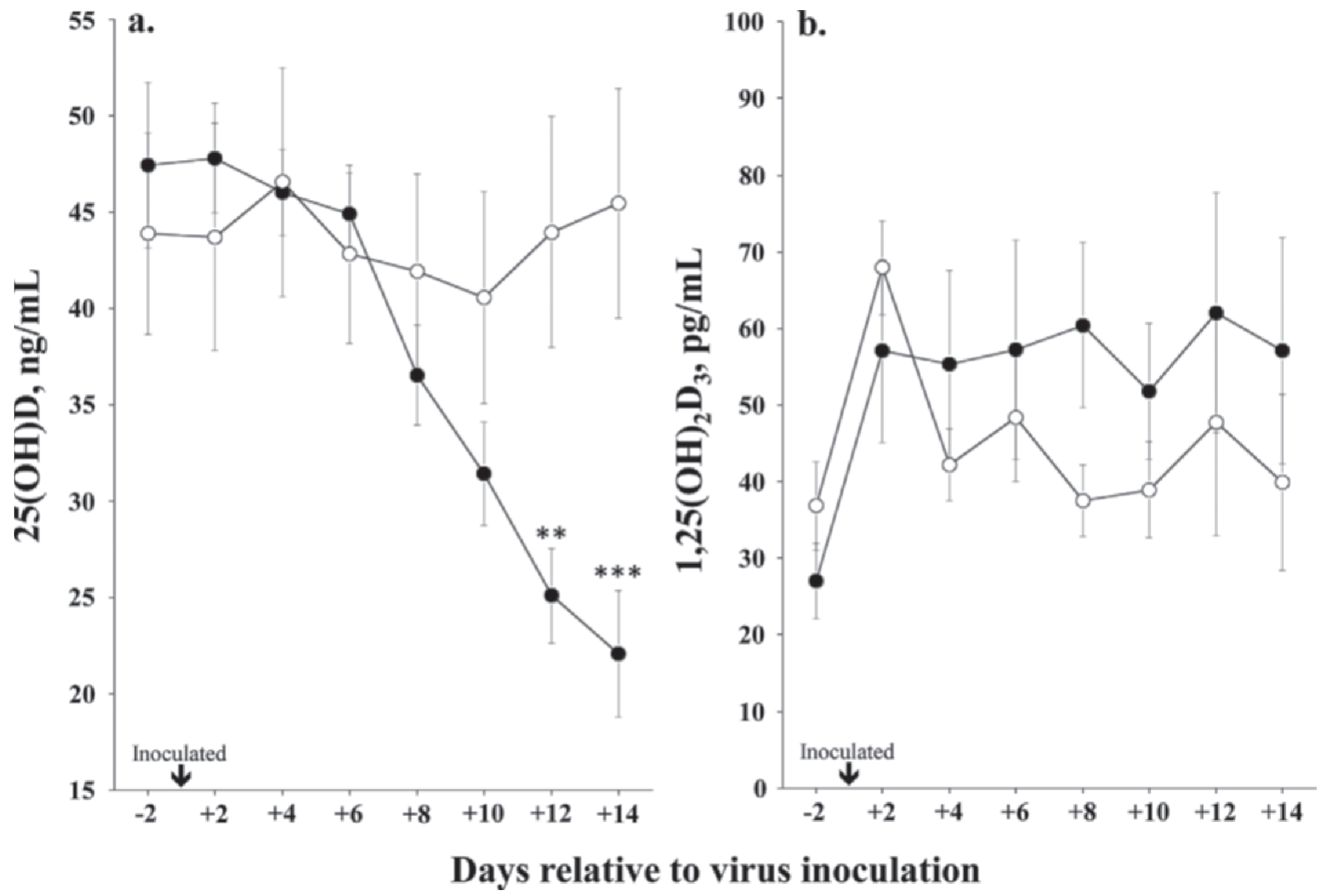

Figure 4. Mean $\left( \pm\right.$ SEM) 25-hydoxyvitamin D $\left[25(\mathrm{OH}) \mathrm{D}\right.$, panel a] and 1,25-dihydroxyvitamin $\mathrm{D}_{3}\left[1,25(\mathrm{OH})_{2} \mathrm{D}_{3}\right.$, panel b] concentrations in serum from calves mock-inoculated with virus-free culture lysate $(\mathrm{n}=6, \mathrm{O})$ or culture lysate containing bovine viral diarrhea virus (BVDV; $\mathrm{n}$ $=6, \bullet)$. Calves were inoculated on $\mathrm{d} 0$ (indicated by arrow on abscissa). Treatment means that differed on a specific day are indicated by $* * P$ $<0.05$ and ${ }^{* * *} P<0.01$

populations, promote Th2 cytokine production, inhibit IL-17 secretion by $\mathrm{T}_{17}$ cells, and induce development of regulatory $\mathrm{T}$ cells (Tregs) associated with the dampening of excessive immune responses (reviewed by Hewison, 2010).

Recent reports confirm that the vitamin D signaling pathway is operational in the bovine immune system (Lippolis et al., 2011; Nelson et al., 2010a,b, 2011). The most relevant of these to the current study demonstrate that $C Y P^{27 B 1}$ gene expression in macrophages from mammary glands infected with Streptococcus uberis is upregulated, resulting in significant local production of $1,25(\mathrm{OH})_{2} \mathrm{D}_{3}$ (Nelson et al., 2010a), and that intramammary infusion of $25(\mathrm{OH}) \mathrm{D}$ into mammary glands manifesting acute Strep. uberis mastitis reduces bacterial counts in milk and severity of clinical symptoms, presumably by acting as a substrate for intracrine production of $1,25(\mathrm{OH})_{2} \mathrm{D}_{3}$. Extending these observations to those of the present study, it is possible that a significant contributor to the rapid decrease in the vitamin D status of BVDV-infected calves was due to increased intracrine conversion of serum $25(\mathrm{OH}) \mathrm{D}$ to $1,25(\mathrm{OH})_{2} \mathrm{D}_{3}$ and likely other vitamin $\mathrm{D}$ metabolites by immune cells at the site of infection and possibly systemically. Conceivably, the pronounced acute phase response and increased cytokine levels in the peripheral circulation and presumably in affected tissues resulted in sustained expression of $C Y P 27 B 1$ and $C Y P 24 A 1$ $\left[1,25(\mathrm{OH})_{2} \mathrm{D}_{3}\right.$ 24-hydroxylase], the latter catalyzing inactivation of $1,25(\mathrm{OH})_{2} \mathrm{D}_{3}$, thus limiting its excess production. In the present study, elevated IFN- $\gamma$ levels in the circulation at the time of declining vitamin D status suggest a role for this cytokine in loss of serum $25(\mathrm{OH}) \mathrm{D}$ attributable to its intracrine conversion to $1,25(\mathrm{OH})_{2} \mathrm{D}_{3}$ and its breakdown. This possibility is supported by research indicating that IFN- $\gamma$ stimulates $1,25(\mathrm{OH})_{2} \mathrm{D}_{3}$ production by human macrophages via its enhancing effects on $C Y P{ }^{27} 7 B 1$ gene expression (Koef- 
fler et al., 1985). Recent research (Nelson et al., 2011) suggests that intracrine production of $1,25(\mathrm{OH})_{2} \mathrm{D}_{3}$ by bovine $\mathrm{B}$ cells and monocytes results in downregulation of antigen-elicited IFN- $\gamma$ secretion by $\mathrm{T}$ cells. Recognizing this possibility, the rise and subsequent decline in serum IFN- $\gamma$ concentrations in the present study may reflect the effects of intracrine production of $1,25(\mathrm{OH})_{2} \mathrm{D}_{3}$ on this particular cytokine.

\section{Serum 1,25(OH) ${ }_{2} D_{3}$ Concentrations in Control and BVDV-Infected Calves}

In the classical endocrine vitamin D pathway, $25(\mathrm{OH})$ $\mathrm{D}$ is hydroxylated to $1,25(\mathrm{OH})_{2} \mathrm{D}_{3}$ in the kidneys by the enzyme CYP27B1 in a tightly regulated process that is stimulated by parathyroid hormone under conditions of declining extracellular (i.e., blood) calcium and phosphorous concentrations. Then, $1,25(\mathrm{OH})_{2} \mathrm{D}_{3}$ enters the circulation and acts as a classical steroid hormone, enhancing calcium and phosphorous uptake from the gastrointestinal tract and promoting skeletal homeostasis through effects on cells such as bone-forming osteoblasts (Horst et al., 1994).

In the present study, serum $1,25(\mathrm{OH})_{2} \mathrm{D}_{3}$ concentrations in control and infected calves (Figure 4b) did not differ $(P=0.37)$ during the PIP, indicating that BVDV infection did not influence circulating concentrations of this biologically active metabolite of vitamin D. Values were comparable to previously reported serum $1,25(\mathrm{OH})_{2} \mathrm{D}_{3}$ concentrations in the preruminant calf (Rajaraman et al., 1997; Nonnecke et al., 2009b). In addition, the association between serum $25(\mathrm{OH}) \mathrm{D}$ and $1,25(\mathrm{OH})_{2} \mathrm{D}_{3}$ concentrations was not significant when values for all calves across 8 sampling times were used in the analysis $(\mathrm{r}=0.12, P=0.24, \mathrm{n}=96)$. Previous reports (reviewed by Jones, 2008) indicate that only very low or high serum $25(\mathrm{OH}) \mathrm{D}$ concentrations are associated with perturbations in serum $1,25(\mathrm{OH})_{2} \mathrm{D}_{3}$ concentrations. The $25(\mathrm{OH}) \mathrm{D}$ concentrations in infected calves during the latter part of the PIP were lower than at the time of virus inoculation but still sufficiently high to be considered indicative of vitamin D insufficiency rather than deficiency. Additionally, serum $1,25(\mathrm{OH})_{2} \mathrm{D}_{3}$ concentrations are not proportional to the availability of $25(\mathrm{OH}) \mathrm{D}$ but rather contingent upon low extracellular calcium triggering parathyroid hormone-stimulated renal production of $1,25(\mathrm{OH})_{2} \mathrm{D}_{3}$ catalyzed by CYP27B1 in proximal tubule cells of the kidney (Jurutka et al., 2007).

\section{Infection-Induced Decrease in Vitamin E Status}

Numerous studies have demonstrated the role of vitamin $\mathrm{E}$ in assuring optimal health and immune function in young and adult dairy cattle (Weiss, 1998; Politis, 2012). The majority of these considered the effect of vitamin E deficiency or supplementation on disease susceptibility and the effects of vitamin E on ex vivo functional capacities of bloodborne leukocyte populations. Few have considered the effect of infection on vitamin E status; however, acute mastitis elicited by intramammary infusion of LPS or viable $E$. coli is associated with increased $\alpha-T$ concentrations in milk but not plasma from dairy cows (Barrett et al., 1997). There is a dearth of information regarding the effects of acute infections on the vitamin E status of neonatal animals including the vitamin E-replete preruminant dairy calf.

Serum $\alpha-T$ concentrations in control and virusinoculated calves are shown in Figure 5. Preinoculation $\alpha-T$ concentrations in control and infected calves were not different and exceeded $3 \mu \mathrm{g} / \mathrm{mL}$ in both groups. These values are indicative of vitamin E adequacy in young and adult dairy cattle (Rajaraman et al., 1997; Nonnecke et al., 1999). Changes in $\alpha-T$ concentrations observed in infected calves during the PIP followed a pattern similar to that observed for serum $25(\mathrm{OH}) \mathrm{D}$. During the PIP, $\alpha-T$ concentrations were lower $(P>$ $0.05)$ in infected calves than noninfected calves on $\mathrm{d} 10$, 12 , and 14 . When considering only infected calves, $\alpha-T$ concentrations on d 4, 6, 8, 10, 12, and 14 of the PIP were lower $(P<0.05)$ than the preinoculation concentration $(4.37 \mu \mathrm{g} / \mathrm{mL})$. During the 8 -d period spanning d 6 to 14 of PIP, mean $\alpha$-T concentrations decreased from 3.33 to $0.59 \mu \mathrm{g} / \mathrm{mL}$, a reduction of $82 \%$. Mean $\alpha-\mathrm{T}$ concentrations in noninfected calves remained unchanged $(P>0.05)$ during the study, ranging from 2.30 to $3.09 \mu \mathrm{g} / \mathrm{mL}$.

These results are the first to demonstrate that an acute viral infection in vitamin E-replete, preruminant dairy calves is associated with a rapid decrease in vitamin E status that exceeds the estimated normal turnover (i.e., half-life) of plasma $\alpha-\mathrm{T}$ in healthy individuals (i.e., humans; Novotny et al., 2012). The turnover of $\alpha-T$ in young ruminants has not been documented. When comparing effects of acute BVDV infection on vitamin $\mathrm{D}$ and $\mathrm{E}$ status, it is apparent that the rate of loss of $\alpha$ - $T$ was even more pronounced than that observed for $25(\mathrm{OH}) \mathrm{D}$ in the same calves. The dramatic decrease in vitamin $\mathrm{E}$ availability in infected calves cannot be explained entirely by reduced milk replacer intake and suggests that the acute clinical response elicited by BVDV infection was a major factor. In infected calves, serum $\alpha-\mathrm{T}$ and $25(\mathrm{OH}) \mathrm{D}$ concentrations were negatively correlated with the concentrations of the acute phase protein SAA (Figure 6), suggesting that the acute phase response and possibly the associated cytokine release were contributory to the decreased vitamin $\mathrm{E}$ as well as vitamin $\mathrm{D}$ status. 


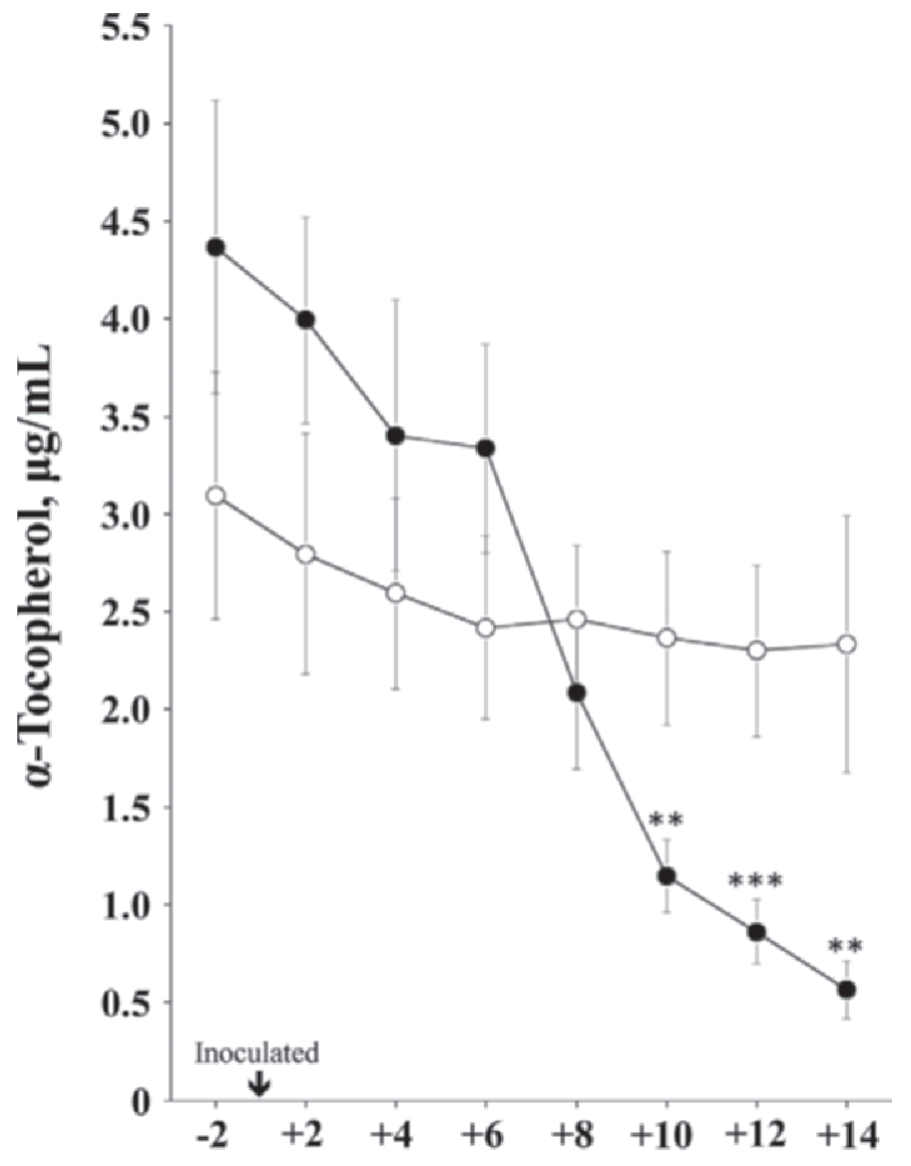

Days relative to virus inoculation

Figure 5. Comparison of mean $( \pm$ SEM) $\alpha$-tocopherol concentrations in serum from calves mock-inoculated with virus-free culture lysate $(\mathrm{n}=6, \mathrm{O})$ or culture lysate containing bovine viral diarrhea virus (BVDV; $\mathrm{n}=6, \mathbf{0}$ ). Calves were inoculated on $\mathrm{d} 0$ (indicated by arrow on abscissa). Treatment means that differed on a specific day are indicated by ${ }^{* *} P<0.05$ and $* * * P<0.01$.

$\alpha$-Tocopherol functions as a chain-breaking antioxidant with the capacity to inhibit or prevent free-radicalmediated peroxidative damage to cells. Quantitatively, it accounts for most of the lipid-soluble antioxidant in mammalian tissues and plasma (reviewed by Burton, 1994). Viral-induced activation of the calf's immune system likely would have resulted in substantially increased production of oxygen radicals by a variety of immune cells with the predominant source being responding (i.e., activated) mononuclear or macrophages and neutrophils. In the present study, the $90 \%$ decrease in serum $\alpha-T$ concentrations in infected calves over an 8-d period suggests the occurrence of dramatically increased production of free radicals that may have depleted the lipid-phase antioxidant capacity of the calf, negatively affecting the functional capacity of cells of the calf's immune system. As summarized by Burton
(1994), determinants of vitamin E turnover likely include (1) the free radical burden imposed on vitamin E stores; (2) the extent to which vitamin $\mathrm{E}$ is spared or regenerated from the tocopheroxyl radical by vitamin $\mathrm{C}$ and ubiquinol (reduced coenzyme Q); (3) the rate of cell turnover; and (4) cellular and extracellular mechanisms that control the traffic of vitamin $\mathrm{E}$ to and from tissues. New research is necessary to determine if free radical burden or a reduced capacity to regenerate vitamin $\mathrm{E}$ from the tocopheroxyl radical contributed to the reduced vitamin $\mathrm{E}$ status of infected calves. In addition, effects of antioxidant intervention (i.e., increased vitamin $\mathrm{E}$ or vitamin $\mathrm{C}$ ) during PIP on the severity and duration of the viral infection in vitamin-replete and vitamin-insufficient preruminant calves should be considered.

For infected calves, we detected negative correlations between $25(\mathrm{OH}) \mathrm{D}$ and SAA concentrations $(\mathrm{r}=-0.61$; $P<0.0001, \mathrm{n}=48$; Figure $6 \mathrm{a})$ and $\alpha-\mathrm{T}$ and SAA concentrations ( $\mathrm{r}=-0.53, P<0.0006, \mathrm{n}=48)$; Figure $6 \mathrm{~b})$; and a positive correlation between $25(\mathrm{OH}) \mathrm{D}$ and $\alpha-\mathrm{T}$ concentrations $(\mathrm{r}=0.70, P<0.0001, \mathrm{n}=48$; Figure $6 \mathrm{c})$. Correlations between $25(\mathrm{OH}) \mathrm{D}$ and haptoglobin and between $\alpha-\mathrm{T}$ and haptoglobin were not significant $(P>0.05)$. The relatively strong associations between both vitamins and SAA during the PIP suggest the potential utility of these variables alone or together as predictors of the severity of infection in preruminant calves. The somewhat indiscriminant and pronounced effects of BVDV infection on the availability of 2 vitamins with differing biological functions suggest that the severity of this particular infection affected broad aspects of the physiology of the preruminant calf.

\section{Serum Y-Tocopherol Concentrations in Noninfected and BVDV-Infected Calves}

$\gamma$-Tocopherol is present in the circulation of humans (Wagner et al., 2004) at approximately $10 \%$ of $\alpha-\mathrm{T}$ concentrations. Because recent studies suggest that the immunomodulatory activity of $\gamma$-T differs from that of $\alpha-T$ (Berdnikovs et al., 2009; Abdala-Valencia et al., 2013), serum $\gamma$-T concentrations in noninfected and infected calves were evaluated concurrently with $\alpha-T$ levels. Previous research (Ametaj et al., 2000) indicates that serum $\gamma$-T in preruminant calves is undetectable at birth and present at 4 to $10 \%$ of $\alpha$-T concentrations from 2 to $28 \mathrm{~d}$ of age. In the present study, $\gamma-\mathrm{T}$ was detectable at very low concentrations in all calves before inoculation $(16.5 \pm 10.3 \mathrm{ng} / \mathrm{mL},<0.5 \%$ of $\alpha-\mathrm{T}$ concentrations) and undetectable in all calves from $\mathrm{d} 4$ to 14 (data not shown), indicating that this tocopherol isoform was not a factor when considering the effect of BVDV infection on vitamin E status. 

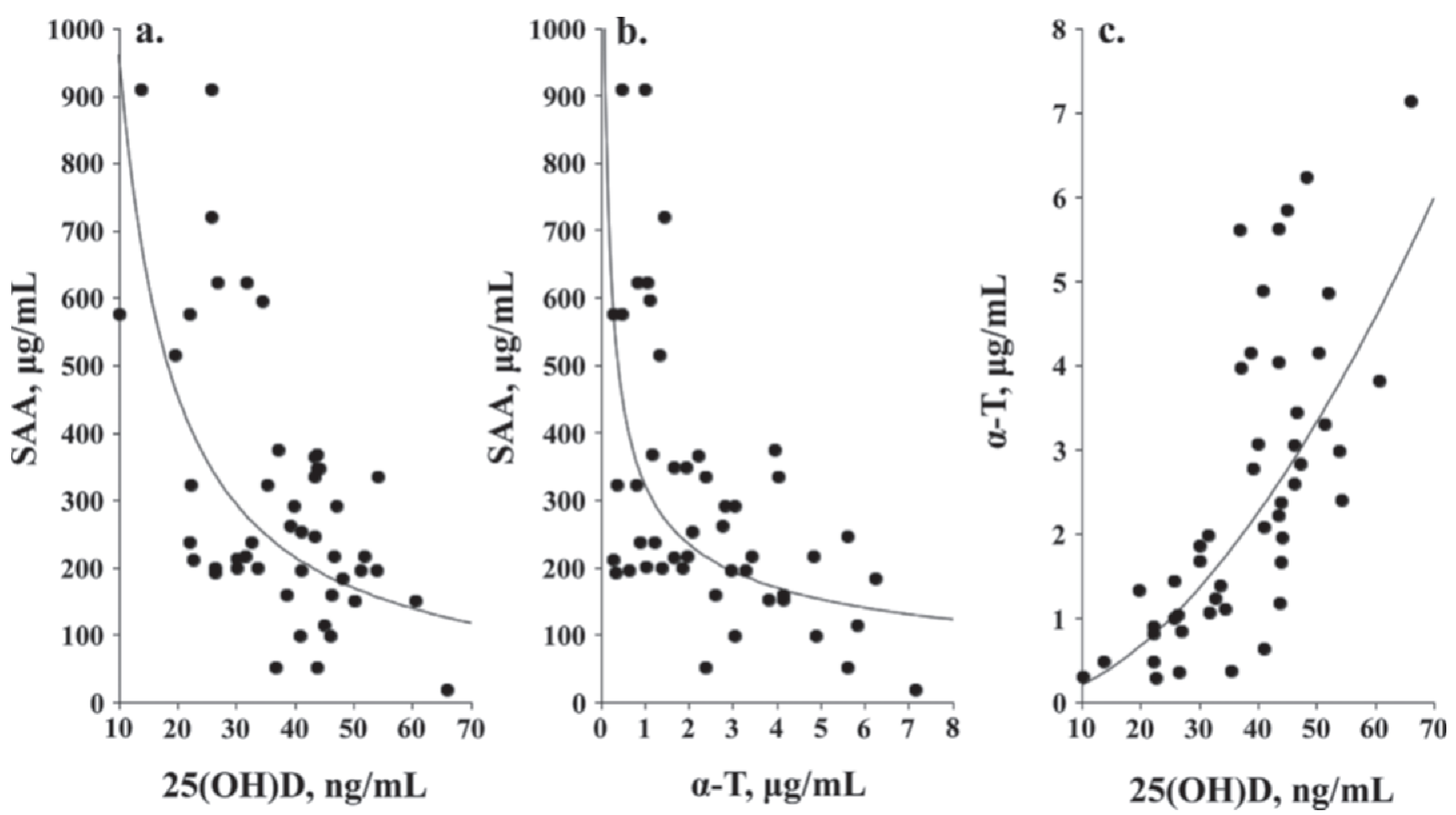

Figure 6. Regression plots depicting significant associations between 25-hydroxyvitamin $\mathrm{D}_{3}[25(\mathrm{OH}) \mathrm{D}]$ and serum amyloid A (SAA, panel $\mathrm{a} ; \mathrm{r}=0.61, P<0.0001)$, $\alpha$-tocopherol $(\alpha-\mathrm{T})$ and SAA (panel $\mathrm{b}, \mathrm{r}=0.53, P<0.0006)$, and $25(\mathrm{OH}) \mathrm{D}$ and $\alpha-\mathrm{T}(\mathrm{panel} \mathrm{c}, \mathrm{r}=0.70, P<0.0001)$ in the circulation of bovine viral diarrhea virus (BVDV)-inoculated calves. Samples were collected from $-2 \mathrm{~d}$ to $+14 \mathrm{~d}$ relative to the day of inoculation. The corresponding associations in control (mock-inoculated) calves were not significant $(P>0.05)$ and are not shown.

\section{CONCLUSIONS}

This report is the first to describe the negative effect of an acute viral infection on the vitamin D and E status of vitamin-replete neonatal calves. The clinical response elicited by the infection was associated with increases in haptoglobin and SAA as well as serum IFN- $\gamma$, IL-2, and IL-6. Concurrent with these changes was a rapid decrease in vitamin status during the postinfection period. Associations between SAA and serum vitamin D and E concentrations suggest a contributory role of the acute phase; however, mechanisms underlying the rapid, potentially negative changes in vitamin $\mathrm{D}$ and $\mathrm{E}$ status of infected calves warrant further investigation. An important question is whether these effects are specific to this infection model or are representative of the neonate's response to acute infection. Effects of additional vitamin $\mathrm{D}$, alone or in combination with vitamin $\mathrm{E}$, during the early phase of infection on disease severity and duration, and the effects of preexisting vitamin insufficiency at the time of infection warrant investigation.

\section{ACKNOWLEDGMENTS}

Authors thank Tracy Porter, Derrel Hoy, Patricia Federico, and Kathryn McMullen for technical assis- tance, veterinarians Rebecca Madison and Jean Hall, and animal caretakers Jeremy Spieker, Brian Conrad, and John Kent for veterinary care and animal husbandry. All are employees of the USDA-Agricultural Research Service and are stationed at the National Animal Disease Center (Ames, IA).

\section{REFERENCES}

Abdala-Valencia, H., S. Berdnikovs, and J. M. Cook-Mills. 2013. Vitamin $\mathrm{E}$ isoforms as modulators of lung inflammation. Nutrients 5:4347-4363.

Ametaj, B. N., D. C. Beitz, T. A. Reinhardt, and B. J. Nonnecke. 1996. 1,25-Dihydroxyvitamin $\mathrm{D}_{3}$ inhibits secretion of interferon- $\gamma$ by mitogen- and antigen-stimulated bovine mononuclear leukocytes. Vet. Immunol. Immunopathol. 52:77-90.

Ametaj, B. N., B. J. Nonnecke, S. T. Franklin, R. L. Horst, W. R. Bidlack, R. L. Stuart, and D. C. Beitz. 2000. Dietary vitamin A modulates the concentration of $R R R$ - $\alpha$-tocopherol in serum lipoproteins from calves fed milk-replacer. J. Nutr. 130:629-636.

Autier, P., B. Boniol, C. Pizot, and P. Mullie. 2014. Vitamin D status and ill health: A systematic review. Lancet Diabetes Endocrinol. 2:76-89.

Barrett, J. J., J. S. Hogan, W. P. Weiss, K. L. Smith, and L. M. Sordillo. 1997. Concentrations of $\alpha$-tocopherol after intramammary infusion of Escherichia coli or lipopolysaccharide. J. Dairy Sci. $80: 2826-2832$

Battersby, A. J., B. Kampmann, and S. Burl. 2012. Vitamin D in early childhood and the effect on immunity to Mycobacterium tuberculosis. Clin. Dev. Immunol. 2012:430972. 
Bauermann, F. V., E. F. Flores, J. E. Ridpath, and J. D. Neill. 2012. Antigenic relationships between bovine viral diarrhea virus 1 and 2 and $\mathrm{HoBi}$ virus: Possible impacts on diagnosis and control. J. Vet. Diagn. Invest. 24:253-261.

Beck, M. A. 2007. Selenium and vitamin E status: Impact on viral pathogenicity. J. Nutr. 137:1338-1340.

Berdnikovs, S., H. Abdala-Valencia, C. McCary, M. Somand, R. Cole, A. Garcia, P. Bryce, and J. M. Cook-Mills. 2009. Isoforms of vitamin $\mathrm{E}$ have opposing immunoregulatory functions during inflammation by regulating leukocyte recruitment. J. Immunol. 182:4395-4405.

Burton, G. W. 1994. Vitamin E: Molecular and biological function. Proc. Nutr. Soc. 53:251-262.

Carman, S., T. van Druemel, J. Ridpath, M. Hazlett, D. Alves, E. Dubovi, R. Tremblay, S. Bolin, A. Godkin, and N. Anderson. 1998. Severe acute bovine diarrhea in Ontario, 1993-1995. J. Vet. Diagn. Invest. 10:27-35.

Ceciliani, F., J. J. Ceron, P. D. Eckersall, and H. Sauerwein. 2012 Acute phase proteins in ruminants. J. Proteomics 75:4207-4231.

Cipriano, J. E., J. L. Morrill, and N. V. Anderson. 1982. Effect of dietary vitamin $\mathrm{E}$ on immune responses of calves. J. Dairy Sci. 65:2357-2365

de la Rosa, M., S. Rutz, H. Dorninger, and A. Scheffold. 2004. Interleukin-2 is essential for $\mathrm{CD} 4^{+} \mathrm{CD} 25^{+}$regulatory $\mathrm{T}$ cell function. Eur. J. Immunol. 34:2480-2488.

Eicher-Pruiett, S. D., J. L. Morrill, F. Blecha, J. J. Higgins, N. V. Anderson, and P. G. Reddy. 1992. Neutrophil and lymphocyte response to supplementation with vitamins $\mathrm{C}$ and $\mathrm{E}$ in young calves. J. Dairy Sci. 75:1635-1642.

Endsley, J. J., W. R. Waters, M. V. Palmer, B. J. Nonnecke, T. C. Thacker, W. R. Jacobs Jr., M. H. Larsen, A. Hogg, E. Shell, M. McAlauy, C. F. Scherer, T. Coffey, C. J. Howard, B. VillarealRamos, and D. M. Estes. 2009. The calf model of immunity for development of a vaccine against tuberculosis. Vet. Immunol. Immunopathol. 128:199-204.

Evans, H. M., and K. S. Bishop. 1922. On the existence of a hitherto unrecognized dietary factor essential for reproduction. Science $56: 650-651$.

Grönlund, U., C. Hulten, P. D. Eckersall, C. Hogarth, and K. P. Waller. 2003. Haptoglobin and serum amyloid A in milk and serum during acute and chronic experimentally induced Staphylococcus aureus mastitis. J. Dairy Res. 70:379-386.

Heegaard, P. M. H., D. L. Godson, M. J. M. Toussaint, K. Tjornehoj, L. E. Larsen, B. Viuff, and L. Ronsholt. 2000. The acute response of haptoglobin and serum amyloid A (SAA) in cattle undergoing experimental infection with bovine respiratory syncytial virus. Vet. Immunol. Immunopathol. 77:151-159.

Hein, W. R., and C. R. Mackay. 1991. Prominence of $\gamma \delta$ T cells in the ruminant immune system. Immunol. Today 12:30-34.

Hewison, M. 2010. Vitamin D and the intracrinology of innate immunity. Mol. Cell. Endocrinol. 321:103-111.

Higuchi, H., and H. Nagahata. 2000. Effects if vitamins A and E on superoxide production and intracellular signaling of neutrophils in Holstein calves. Can. J. Vet. Res. 64:69-75.

Holick, M. F. 2009. Vitamin D status: Measurement, interpretation, and clinical applications. Ann. Epidemiol. 19:73-78.

Hollis, B. W., J. Q. Kamerud, A. Kurkowski, J. Beaulieu, and J. L. Napoli. 1996. Quantification of circulating 1,25-dihydroxyvitamin D by radioimmunoassay with an ${ }^{125}$ I-lableled tracer. Clin. Chem. 42:586-592.

Hollis, B. W., J. Q. Kamerud, S. R. Selvaag, J. D. Lorenz, and J. L. Napoli. 1993. Determination of vitamin D status by radioimmunoassay with an ${ }^{125}$ I-labeled tracer. Clin. Chem. 39:529-533.

Horst, R. L., J. P. Goff, and T. A. Reinhardt. 1994. Calcium and vitamin D metabolism in the dairy cow. J. Dairy Sci. 77:1936-1951.

Jacobsen, S., P. H. Andersen, T. Toelboell, and P. M. H. Heegaard. 2004. Dose dependency and individual variability of the lipopolysaccharide-induced bovine acute phase protein response. J. Dairy Sci. 87:3330-3339.

Jones, G. 2008. Pharmokinetics of vitamin D toxicity. Am. J. Clin. Nutr. 88:582S-586S.
Jurutka, P. W., L. Bartik, G. K. Whitfield, D. R. Mathern, T. K. Barthel, M. Gurevich, J. C. Hsieh, M. Kaczmarska, C. A. Haussler, and M. R. Haussler. 2007. Vitamin D receptor: Key roles in bone mineral pathophysiology, molecular mechanism of action, and novel nutritional ligands. J. Bone Miner. Res. 22(Suppl. 2):V2-V10.

Kaplan, L. A., J. A. Miller, and E. A. Stein. 1987. Simultaneous measurement of serum retinol, tocopherols, carotenes, and carotenoids by high performance liquid chromatography. J. Clin. Lab. Anal. $1: 147-152$.

Kelling, C. L., and C. L. Topliff. 2013. Bovine maternal, fetal and neonatal responses to bovine viral diarrhea virus infections. Biologicals 41:20-25.

Koeffler, H. P., H. Reichel, J. E. Bishop, and A. W. Norman. 1985 Gamma-interferon stimulates production of 1,25-dihydroxyvitamin $\mathrm{D}^{3}$ by normal human macrophages. Biochem. Biophys. Res. Commun. 127:596-603.

Kreuger, L. A., D. C. Beitz, K. Onda, M. Osman, M. R. O'Neil, R. Stuart, H. D. Tyler, and B. J. Nonnecke. 2014. Effects of D- $\alpha-$ tocopherol and dietary energy on growth and health of preruminant dairy calves. J. Dairy Sci. 97:3716-3727. http://dx.doi. org/10.3168/jds.2013-7315.

Liebler-Tenorio, E. M., J. F. Ridpath, and J. D. Neill. 2002. Distribution of viral antigen and development of lesions after experimental infection with highly virulent bovine viral diarrhea virus type 2 in calves. Am. J. Vet. Res. 63:1575-1584.

Lippolis, J. D., T. A. Reinhardt, R. A. Sacco, B. J. Nonnecke, and C. D. Nelson. 2011. Treatment of an intramammary bacterial infection with 25-hydroxyvitamin $\mathrm{D}_{3}$. PLoS ONE 6:e25479.

McGill, J. L., B. J. Nonnecke, J. D. Lippolis, T. A. Reinhardt, and R. E. Sacco. 2013. Differential chemokine and cytokine production by neonatal bovine $\gamma \delta$ T-cell subsets in response to viral toll-like receptor agonists and in vivo respiratory syncytial virus infection. Immunology 139:227-244.

McNally, J. D., K. Leis, L. A. Matheson, C. Karuananyake, K. Sankaran, and A. M. Rosenberg. 2009. Vitamin D deficiency in young children with severe acute lower respiratory tract infection. Pediatr. Pulmonol. 44:981-988.

Molina, V. M., A. Risalde, P. J. Sanchez-Cordon, F. Romero-Palomo, M. Pedrera, B. Garfia, and J. C. Gomez-Villamandos. 2012 Cell-mediated immune response during experimental acute infection with bovine diarrhoea virus: Evaluation of blood parameters. Transbound. Emerg. Dis. http://dx.doi.org/10.1111/tbed.12002.

Mosmann, T. R., and R. L. Coffman. 1989. TH1and TH2 cells: Different patterns of lymphocyte secretion lead to different functional properties. Annu. Rev. Immunol. 7:145-173.

Müller-Doblies, D., A. Arquint, P. Schaller, P. M. H. Heegaard, M. Hilbe, S. Albini, C. Abril, K. Tobler, F. Ehrensperger, E. Peterhans, M. Ackerman, and A. Metzler. 2004. Innate immune responses of calves during transient infection with a noncytopathic strain of bovine viral diarrhea virus. Clin. Diagn. Lab. Immunol. 11:302-312.

National Animal Health Monitoring Service. 2012. Diary heifer raiser, 2011. \#613.1012. USDA Animal and Plant Health Inspection Service (APHIS), Veterinary Services, Ames, IA.

Nelson, C. D., B. J. Nonnecke, T. A. Reinhardt, W. R. Waters, D. C. Beitz, and J. D. Lippolis. 2011. Regulation of Mycobacteriumspecific mononuclear cell responses by 25-hydroxvitamin $\mathrm{D}_{3}$. PLoS ONE 6:e21674.

Nelson, C. D., T. A. Reinhardt, D. C. Beitz, and J. D. Lippolis. 2010a. In vivo activation of the intracrine vitamin $\mathrm{D}$ pathway in innate immune cells and mammary tissue during a bacterial infection. PLoS ONE 5:e15469.

Nelson, C. D., T. A. Reinhardt, J. D. Lippolis, R. E. Sacco, and B. J. Nonnecke. 2012. Vitamin D signaling in the bovine immune system: A model for understanding human vitamin D requirements. Nutrients 4:181-196.

Nelson, C. D., T. A. Reinhardt, T. C. Thacker, D. C. Beitz, and J. D Lippolis. 2010b. Modulation of the bovine innate immune response by production of $1 \alpha, 25$-dihydroxyvitamin $\mathrm{D}_{3}$ in bovine monocytes. J. Dairy Sci. 93:1041-1049. 
Nonnecke, B. J., M. R. Foote, B. L. Miller, D. C. Beitz, and R. L. Horst. 2010. Short communication: Fat-soluble vitamin and mineral status of milk replacer-fed dairy calves: Effect of growth rate during the preruminant period. J. Dairy Sci. 93:2684-2690.

Nonnecke, B. J., M. R. Foote, B. L. Miller, M. Fowler, T. E. Johnson, and R. L. Horst. 2009a. Effects of chronic environmental cold on growth, health, and select metabolic and immunologic responses of preruminant calves. J. Dairy Sci. 92:6134-6143.

Nonnecke, B. J., R. L. Horst, W. R. Waters, P. Dubeski, and J. A. Harp. 1999. Modulation of fat-soluble vitamin concentrations and blood mononuclear leukocyte populations in milk replacerfed calves by dietary vitamin A and $\beta$-carotene. J. Dairy Sci. 82:2632-2641.

Nonnecke, B. J., T. A. Reinhardt, and W. R. Waters. 2009b. Short communication: The preruminant calf as a model for characterizing the effects of vitamin D status in the neonate. J. Dairy Sci. 92:5692-5696.

Novotny, J. A., J. G. Fadel, D. M. Holstege, H. C. Furr, and A. J. Clifford. 2012. This kinetic, bioavailability, and metabolism study of $\mathrm{RRR}$ - $\alpha$-tocopherol in healthy adults suggests lower intake requirements than previous estimates. J. Nutr. 142:2105-2111.

NRC. 2001. Nutrient Requirements of Dairy Cattle. 7th rev. ed. Natl. Acad. Press, Washington, DC.

Politis, I. 2012. Reevaluation of vitamin E supplementation of dairy cows: bioavailability, animal health, and milk quality. Animal 6:1427-1434.

Rajaraman, V., B. J. Nonnecke, and R. L. Horst. 1997. Effects of replacement of native fat in colostrum and milk with coconut oil on fat-soluble vitamins in serum and immune function in calves. J. Dairy Sci. 80:2380-2390.

Rhodes, S. G., J. M. Cocksedge, R. A. Collins, and W. I. Morrison. 1999. Differential cytokine responses of $\mathrm{CD} 4^{+}$and $\mathrm{CD} 8^{+} \mathrm{T}$ cells in response to bovine viral diarrhoea virus in cattle. J. Gen. Virol. 80:1673-1679.

Ridpath, J. F., S. M. Falkenberg, F. V. Bauermann, B. L. Vanderlay, D. YoonJung, E. F. Flores, D. J. Rodman, and J. D. Neill. 2013.
Comparison of acute infection of calves exposed to a high-virulence or low-virulence bovine diarrheal virus or a HoBi-like virus. Am. J. Vet. Res. 74:438-442.

Ridpath, J. F., J. D. Neill, S. Vilcek, E. J. Dubovi, and S. Carman. 2006. Multiple outbreaks of severe acute BVDV in North America occurring between 1993 and 1995 linked to the same BVDV2 strain. Vet. Microbiol. 114:196-204.

Sacco, R. E., B. J. Nonnecke, M. V. Palmer, W. R. Waters, J. D. Lippolis, and T. A. Reinhardt. 2012. Differential expression of cytokines in response to respiratory syncytial infection of calves with high and low circulating 25-hydroxyvitamin D3. PLoS ONE 7:e33074. http://dx.doi.org/10.1371/journal.pone.0033074.

Seong, G., J. Oem, and K. Choi. 2013. Pathogenic differences after experimental infection of calves with Korean non-cytopathic BVDV-1 and BVDV-2 isolates. Vet. Immunol. Immunopathol. 156:147-152.

Sorge, U. S., T. Molitor, J. Linn, D. Gallaher, and S. W. Wells. 2013. Cow-level association between serum 25-hydroxyvitamin D concentration in Mycobacterium avium subspecies paratuberculosis antibody seropositivity: A pilot study. J. Dairy Sci. 96:1030-1037.

Stoffregen, B., S. R. Bolin, J. F. Ridpath, and J. Pohlenz. 2000. Morphologic lesions in type 2 BVDV infections induced by strain BVDV2-1373 recovered from a field case. Vet. Microbiol. 77:157162.

Wagner, K. H., A. Kamal-Eldin, and I. Elmadfa. 2004. Gamma-tocopherol: An underestimated vitamin? Ann. Nutr. Metab. 48:169-188.

Weiss, W. P. 1998. Requirements of fat-soluble vitamins for dairy cows: A review. J. Dairy Sci. 81:2493-2501.

Wolf, G. 2006. How an increased intake of $\alpha$-tocopherol can suppress the bioavailability of gamma-tocopherol. Nutr. Rev. 64:295-299.

Xing, Z., J. Gauldie, G. Cox, H. Baumann, M. Jordana, X. F. Lei, and M. K. Achong. 1998. IL-6 is an anti-inflammatory cytokine required for controlling local or systemic acute inflammatory responses. J. Clin. Invest. 101:311-320. 